\title{
The seeds multiply: the AcampaDOC International Documentary Film Festival
}

\author{
Las semillas se multiplican: el Festival Internacional de Documentales \\ AcampaDOC
}

\section{Jasper Vanhaelemeesch}

jasper.vanhaelemeeschduantwerpen.be University of Antwerp, Antwerp, Belgium

https://orcid.org/0000-0002-0751-8828

\begin{abstract}
Contemporary Central American film cultures can be conceptualized as small, postconflict, and postThird-Worldist cinemas that, in absence of strong state-regulated support structures, have come to rely heavily on their relations to national and regional film festivals. This article focuses on the AcampaDOC International Documentary Film Festival in Panama and its efforts to establish a platform for the training of young Ibero-American filmmakers and for the annual convergence of some of the region's best-connected film professionals as mentors and experts. The paper discusses findings from an ethnographic fieldwork and refers to a network analysis of production relations in the region. The network of film professionals and film festivals, as well as the festival's educational principles, demonstrate an embeddedness in the projects of New Latin American Cinemas and the Escuela Internacional de Cine y Televisión in Cuba.
\end{abstract}

Keywords: Central America; Film festivals; Documentary; Ethnography; Network analysis.

\section{Resumen}

Se puede conceptualizar las actuales culturas cinematográficas de Centroamérica como pequeñas (Hjort \& Petrie, 2007), postconflicto y posttercermundistas (Shohat, 2004), que, en ausencia de estructuras de apoyo reguladas por el Estado, han dependido en gran medida de sus relaciones con festivales de cine nacionales y regionales (Ahn, 2012). Este artículo se centra en el Festival Internacional de Cine Documental AcampaDOC en Panamá y en sus esfuerzos por establecer una plataforma para la formación de jóvenes cineastas iberoamericanos y para la convergencia anual de cineastas de la región como mentores y expertos. El artículo presenta datos obtenidos de un trabajo de campo etnográfico y refiere a un análisis de redes de producción en la región. La red de cineastas y festivales de cine, así como los principios educativos del festival, demuestran un arraigo en los proyectos del Nuevo Cine Latinoamericano y la Escuela Internacional de Cine y Televisión en Cuba.

Palabras clave: Centroamérica; festivales de cine; cine documental; etnografía; análisis de redes. 


\section{Introduction}

Central American film production has expanded significantly over the last two decades, from virtual non-acknowledgement to a combined annual output of around thirty feature-length fiction and documentary films from six countries (Guatemala, Panama, Costa Rica, Nicaragua, Honduras, El Salvador). This cinematographic expansion has coincided with the establishment of several film festivals set up to fill the cultural vacuum that was left after the signing of regional Peace Agreements in 1996, at the beginnings of what is now known as the "postwar era". While national film projects of socially and politically committed filmmaking arose already in, and because of, the tumultuous period of the 1970s and 1980s, recent cinematic developments are framed in light of the social and organizational changes that followed the peak moment of globalization (Flew, 2018).

Despite a newfound freedom of expression, the influx of international development cooperation, and the spread of new technologies, cultural producers were faced with polarized societies and weakened nation-states with little interest in cultural production (Oyamburu, 2000). The "precarious" state of the cultural sectors led to a call for establishing productive networks on a regional scale (Burucúa \& Sitnisky, 2018). As the example of New Latin American Cinemas (NLAC) had already demonstrated in the previous decades, an effective way to organize cultural development was accomplished through the recurring convergence of like-minded creative producers at, for example, film festivals. The Central American film festivals that were set up in the aftermath of the peace negotiations became catalyzing platforms, embodying the principles of creative precarity, and the celebration of commonality and diversity under that regional, Central American, umbrella.

Contemporary, or "new” (Durón, 2014), Central American cinemas can be conceptualized as postconflict, and post-Third-Worldist (Shohat, 2004), small (Hjort \& Petrie, 2007) cinemas that, in absence of strong state-regulated support structures, have come to rely heavily on their relations to national and regional film festivals (Ahn, 2012). This paper introduces empirical findings gained through ethnographic fieldwork at film festivals in the Central American and Caribbean region, with a focus on one film festival case study, the AcampaDOC International Documentary Film Festival in Panama. In addition to findings from interviews and participant observation, the paper also briefly turns to data from a network analysis that connects Central American films and filmmakers. The relational database set up for this purpose includes 5.607 film professionals that are connected to 344 films released in the postconflict era between $1994^{1}$ and 2019. The goal of the network analysis is not to provide absolute data on social connections or nationhood, but to provide approximations of affinity and collaboration in the milieu-building venture of film-cultural development (Hjort, 2010).

\section{EICTV and Central American film cultures}

For many filmmakers, the idea to work towards a regional Central American cinema emerged in Cuba. After the organization of the first International Film Festival of New Latin American Cinema in 1979, the Committee of Latin American Filmmakers (C-CAL) expanded into the Foundation of the New Latin American Cinema (FNCL) in 1985. The FNCL was founded by Gabriel García Márquez, Cuban filmmaker Julio García Espinosa, and Argentinian filmmaker Fernando Birri, and included members from fifteen Latin American countries, Spain, and the United States. Their main project was to build a film school for Third World filmmakers, which resulted in the inauguration of "The School of Three Worlds" in December 1986 at the Finca San Tranquilino in San Antonio de los Baños:

\footnotetext{
Imagine what this School can be when hundreds of students from the three continents have graduated here, have been able to establish links and relationships among themselves, have been able to exchange ideas and experiences (Castro, 2017).
}

The links and relationships that Fidel Castro hoped to see arise from the interaction at this new school, the Escuela Internacional de Cine y Televisión (EICTV), have to a great extent influenced developments in Central American film cultures. The name has since changed from "The School of Three Worlds" to "The School for Every World" (Balaisis, 
2013, p. 192), shedding the tripartite division of the different worlds from a Cold War context that has characterized a lot of the discourse on the Third World and world cinema.

Conceptually, the reasons for stressing regional commonality in Central America can be motivated positively, negatively, or most realistically, through a combination thereof. Negative characterizations refer mainly to political and economic affairs, the continent's history of colonization and imperial rule, of repressive regimes, patriarchal hierarchies, authoritarian regimes, militarization, and structurally ingrained social inequality. More positive aspects that motivate relationality and solidarity emphasize, for example, cultural development, tangible and intangible, ethnic or linguistic heritage. One specifically Central American theme that emerges from the region-wide sense of commonality revolves around the representation of past traumas in cultural narratives. The postmemorial transfer of a violent past onto newer generations combines the traumatic experiences with social and cinematographic acts of resilience and solidarity through the production of films.

Without pursuing exhaustivity, the film festivals mentioned below are considered because they embody several of the more determining factors of contemporary film-cultural developments in Central America. Based on the understanding of festivals as nodal interfaces for film cultures (lordanova, 2015), the research relates to five areas of concentration in the study of film festivals. These refer to the roles and identities of film festivals in small cinemas, as social meeting grounds, cultural gatekeepers, spaces for learning and as potentially expressive of ideological and political perspectives. When these general notions are applied to the studied film festivals, they translate into another five dominant sub themes around which case studies can be structured. In the Central American context, these themes relate to matters of ideology (1); regional cultural integration (2); training and project development (3); industry development and legislation (4); and to matters of cultural and historical memory (5). The particular case study in this paper relates to the third subtheme of training and development at film festivals.

\section{The Central American film festivalscape}

In a necessarily essentializing overview of significant film festivals in Central America and the Caribbean, the International Film Festival of New Latin American Cinema in Havana can be considered as the most influential proponent of the relation between cinema and ideology (1). The festival, commonly known as the Havana Film Festival, represents since 1979 the underlying institutional, practical, and ideological rationale that lies at the foundation of many Central American film festivals. After the Cuban example, two graduates from the EICTV created a non-profit media organization, Casa Comal, and mounted a film festival in Guatemala in 1998. The International Ícaro Film Festival and its satellite events in the region represent the continuation of the EICTV film school's educational paradigm in promoting a regional circuit of festival exhibition and training opportunities for aspiring filmmakers. For over twenty years, their goal has been to regionally integrate film-cultural expressions while attempting to inscribe the project in the national government's annual budget to ensure continuity (2). Along the same educational principles, since 2012 the AcampaDOC International Documentary Film Festival in Panama provides aspiring filmmakers with intense theoretical and hands-on learning experiences to inspire a form of grassroots documentary filmmaking in, about, and for local communities and heritage (3).

The most ambitious and wealthiest of the Central American film festivals is the International Film Festival of Panama. In 2010, one of the co-founders of the Toronto International Film Festival, Henk van der Kolk, retired to Panama with his family and inspired the local government to set up an international film festival in 2012. While the two largest festivals in Costa Rica (see below) and Guatemala are primarily focused on training filmmakers and fostering regional film productions, the Panamanian emphasis lies with industry- and audiencebuilding with ample corporate and public sponsoring (4). Central American film festivals pose a necessary alternative exhibition circuit for local and regional films, since the majority of commercial theaters are dominated by foreign blockbusters. In general, this causes the potential theater runs of local productions to be short-lived and un- 
profitable due to high projection costs, which are not capped for domestic productions. As for feature-length documentaries, it follows that, outside of the festival circuit, chances at exhibition are even more scarce.

Film schools and film festivals are essential to the professionalization of film cultures in the region, since only a minority of Central American countries have effective film legislation in place, and most countries have had film laws awaiting ratification in legislative assemblies for several years already. Film commissions tend to be housed in NGOs or in ministries of commerce, industry, sports, youth, and, but rarely, in the national governments' cultural ministries. As a result, funds and regulations tend to emphasize economic over cultural concerns in their criteria. In spite of the hard-fought positive developments in the Central American cinematic landscape, the region still has very little distribution possibilities for local films, outside of the local film festival circuit and video-on-demand platforms.

The fifth and last subtheme, film festivals' social and political responsibilities in the region, can be highlighted through a broader discussion on the presence of human rights film festivals (Tascón, 2015) that foreground dialogues on ethnic and sexual diversity. One particular human rights-oriented film festival, the International Film Festival of Memory, Truth and Justice in Guatemala, fits the context of the postmemory genre as particularly characteristic of a significant part of postwar Central American film production and exhibition (5).

Chronologically, the first festival that could have been considered in relation to contemporary Central American film cultures is the Costa Rican Showcase for Film and Video which started in 1992 as an exhibition platform for local productions and which expanded to regional and international films by turning into the International Film and Video Festival San José in 2011. In 2012, its name was changed into Costa Rica International Film Festival - Peace on Earth before becoming the Costa Rica International Film Festival (CRFIC) in 2015. In its historical development, scope and objectives, the festival can be situated at a similar footing as the Ícaro Festival. On the surface, CRFIC does not only emphasize its responsibility as an exhibitor of national and regional cinema in an extensive range of urban and rural locations throughout the country, but also organizes talent campuses for emerging filmmakers and a work-in-progress platform for the development of film projects that allows the festival to mediate and strengthen industrial practices on a national and regional scale. The festival is part of the annual operations of the Costa Rican Centro de Cine, which organizes screenings throughout the year under the title "Preámbulo" and manages the operations of the annual "Fauno" film fund (Falicov, 2019; Sánchez, 2018). This integration of initiatives related to programming, industry, education and funding seems to indicate that CRFIC combines some of the defining aspects of the aforementioned festivals.

All three major festivals in the subcontinent, CRFIC, Ícaro, and IFF Panama, together with a range of smaller ones, however, follow in the footsteps of the Havana Film Festival, which continues to hover as a mythical spectre over current developments in contemporary Latin American cinemas. In the following, I discuss one of the few film festivals in Central America with a trajectory of longer than six years that is dedicated exclusively to documentary cinema. The AcampaDOC festival is a representative case study in bringing together some key actors from the Panamanian and Central American film scene and in demonstrating the lasting energy of EICTV's educational paradigm and the collaborative networks among its alumni. However smallscale, the work of the festival's annual participants reverberates throughout the network of Central American film cultures and reaches out to the rest of the Americas.

\section{AcampaDOC}

The AcampaDOC Festival Internacional de Cine Documental is held annually in La Villa de Los Santos at the National School of Folklore. AcampaDOC is a small international film festival in a small Panamanian film culture. In terms of its annual budget, of less than USD 20.000, location, programming, organization, number of visitors, media attention, and other supposed indicators of a festival's size, AcampaDOC is among the smallest events in the region, organized in a village of 8.000 inhabitants located 260 kilometers south of Panama City, the capital. The festival annually exhibits around thirty 
international documentary films to an audience of locals, always relating to a chosen theme that fits in the larger project on the rescuing of tangible and intangible heritage as essential to a peaceful and democratic society.

The annual theme serves as an overarching theoretical framework and guides the festival's selection of tutors and projects to be considered for the workshops. From 2012 until 2021, the guiding themes have been: heritage and society, gastronomic heritage, basin memories, peasant agriculture, cultural landscapes at risk, women and work, living community culture, responsible consumption and production, alternatives after confinement, and, scheduled for 2021, built heritage.

In 2018, the program consisted of thirty-five films from nineteen countries, distributed between the sections Competition and Panorama. AcampaDOC does not only exhibit international documentary films, as they are also Panama's most prolific producer of documentary shorts. Most of the festival's budget is allocated to the travel and accommodation of young film students from the region to follow a week-long training at the festival, during which the students prepare a five-minute documentary in groups of three or four Iprogramme "Campamento" or camp, to which the festival's name refers in a play-on-words). In 2018, there were fourteen students that took part in daily workshops and feedback sessions imparted by film professionals from the region.

In addition to the student camp, the festival also offers a second film lab in which a number of young Ibero-American filmmakers with feature-length works-in-progress are invited to share experiences and improve their own projects through collective and individual sessions with tutors dedicated to development and finetuning of scripts, pitches, distribution strategies, cinematographic language, and other forms of coaching (programme "Residencia" or residencyl. As the result of a strategic alliance, the winner of a pitching exercise receives support to go pitch their project at Bolivia Lab in La Paz.

During the festival, the more experienced residents equally develop a five-minute film in and about $\mathrm{La}$ Villa de Los Santos, with the objective of applying the acquired knowledge to reflect the theme or style of the individual project they were already working on in their respective countries. This way, the festival produced eleven documentary shorts in 2018, most of which are to be submitted to other film festivals in the region or abroad. For example, the sixth edition of the Panalandia Low Budget Film Festival in February 2019 programmed nine out of the eleven shorts produced in September 2018 at AcampaDOC. Panalandia, in turn, collaborates with the Panamanian International Film Festival in Los Angeles to circulate their awarded films overseas, and the US-based Panafest's awarded films are afterwards again exhibited in Panama.

After the festival runs, AcampaDOC submits the films to CurtaDoc, an online platform for documentary shorts based in Brazil. After only seven editions, AcampaDOC already produced between sixty and seventy films in and about La Villa de los Santos. The town has thus become one of the most-documented areas in the region, following the example of the former Cuban military base in San Antonio de Los Baños, home to the EICTV film school and subject of many of its famed film exercises and projects. The idea behind fostering production is to instil a desire to work together, and continue to do so after the festival ends, as explained by festival director Irina Ruiz Figueroa:

[Before 2012], there were no documentaries being made and that year we started with four. The following year we had six, then eight... Today, during the seventh edition, eleven are being produced, and up to fourteen documentaries have been made [during other editions]. We are currently the largest producer of documentary shorts in Panama working on issues of auteur cinema [...] and after the young people leave the camp, they return to their communities to continue producing. So, the idea is this: to germinate all those little seeds here so that later they can always multiply by two and three. (Ruiz Figueroa, I., personal communication, 14 September 2018; own translation).

The engagement with the annual theme and the safeguarding of tangible and intangible heritage does not only extend to the programmed and the produced films, but also to the invitation of the tutors and experts, who are invited based on their relation to the theme:

As every year we decide on a theme, the theoretical framework of the entire festival is marked by a 
person who will inspire that framework. For example, this year we were looking for someone from South America to complement the understanding of Community Living Culture because indigenous societies like the Andean, Aymara, and Quechua understand this concept very well (Ruiz Figueroa, I., personal communication, 14 September 2018; own translation).

The field of cultural production in Central America is characterised by its regional interconnectedness, by a historically, politically and theoretically embedded sense of relationality. This abstract idea became tangible during the process of doing ethnographic fieldwork. At AcampaDOC 2018, Peruvian anthropologist and filmmaker, Carlo Brescia, invited us to partake in a despacho-ceremony of offering to Mother Nature, or Pachamama, involving the ritualistic gathering, burning, and burying of coca leaves. The participants stood in a wide circle, each holding three coca leaves close to their face while incense was burnt to open a sacred space. After breathing on the leaves, participants carefully placed the leaves on a large piece of paper in the center of the room, accompanied by a silent wish or a prayer for something that one wants to achieve. The leaves were then wrapped in a bundle of paper which was taken around the participants circle who were asked to leave their sorrows and negativity with the fire that would consume the leaves, after which the bundle was burnt and buried out of sight by the leader of the ceremony.

The ritualistic offering not only conveyed gratitude to Mother Nature for its resources and energies but also strengthened the ties among the participants, many of whom I would meet again two months later in Guatemala, three months later in Cuba, or six months later in Panama. Brescia, expert on medicinal uses of plants and Andean communities, we playfully termed the festival's own shaman of the high Andes. However unlikely, his and my own paths had actually crossed before, as we both once graduated from the same university programme, years earlier, revealing in fact many mutual connections and experiences. This was the first of many rituals and film festivals that I participated in during a total of five months of fieldwork, but the emphasis on community and connectivity I found throughout the region inspired the theoretical and methodological approach to this topic ${ }^{2}$.
The goal of anthropological fieldwork is to get as close as possible to the "natural context of the subjects involved -everyday life, conversation - in a situation of prolonged interrelations between the researcher in person and the local populations" (Olivier de Sardan, 2015, p. 22). This acknowledgement identifies two issues with studying film festivals ethnographically, since, as an event limited in space and time and specifically constructed to accommodate and pamper its guests, they can hardly be considered as "natural contexts" in which participants can be observed going about routine tasks. Most people who have spent time at a film festival realize how extraordinary and extravagant such an event usually is. A film festival guest cannot be seen as representative for a broader social order, nor can the proceedings be regarded as "everyday representations and practices" for which the fieldwork provides contextualized knowledge $(2015$, p. 22). While some events are more exclusive than others in terms of providing access and credentials to different types of festivalgoers, I reason that, for film-producing individuals, film festivals have become a necessary natural context if one is working in the film industry. The extraordinary nature of such an event is in a way normalized from the perspective of the film professional as festivals become mobile and transient workplaces for many careers in the film industry.

The same rings true for festival researchers. As a white, male, European researcher, I was a foreigner at any given moment during the fieldwork, and insofar one is allowed to gain access to the inner workings of a festival, it can be expected to compensate the effort in a mutually beneficial way. For a number of festivals, this consisted in taking part in the selection committee and the festival jury, in writing festival reviews and sitting for flash interviews about my impressions of the festivals.

Besides the international guest tutors, AcampaDOC relies on a community of experienced film professionals from Panama to complete the teaching staff. Until 2019, Panama didn't have any formal education program dedicated to film production and the GECU Experimental University Film Group as well as smaller collectives such as the Afro-Caribbean Contra-Peso youth organization from Colón or the Cine Animal production company in the capital, offer workshops and short-term courses rather than long-term accredited courses. 
As a didactic platform in Panama, the festival is connected to the region's film schools through the exchange of students and mentors.

In Guatemala, this is the case for Casa Comal, a production company, film school, and organizer of the longest-running Central American film festival, the Ícaro International Film Festival. Two of Casa Comal's Guatemalan film students joined AcampaDOC in 2018, and in return there were six (out of fourteen) of the Campamento students from Peru, Nicaragua, Panama, and Guatemala who participated in the Ibermedia-sponsored meeting of Ibero-American students held during the Ícaro festival organized by Casa Comal in Guatemala two months later. Costa Rica is generally best represented at AcampaDOC due to relatively easy and cheap access to Panama over land and the multitude of private and public schools that offer domestic film training opportunities. The call for proposals is also disseminated by the Nicaraguan film institute and EICTV. In fact, over half of all tutors and professionals at either Casa Comal and AcampaDOC are EICTV-graduates. Others have usually studied abroad in Mexico (CUEC, CCC), Argentina, or Europe. The tight social networks formed by Central American film professionals, film festivals, and film schools constitute an answer to the lack of state funding or public interest, in that the production of films is enabled by education, mutual empowerment and solidarity in and between creative communities, thus echoing the spirit of the $\mathrm{Cu}$ ban film school.

\section{Empowering the fellow filmmaker}

Because students and tutors are invited to adhere to the annual theme, the short documentaries that are produced during the festival form a thematic package. The guiding theme is the first criterion in the selection of collaborators. The second criterion consists in a mutually empowering support, of creating opportunities to grow:

The second criterion is to look for people from here, Central Americans, and almost always they are graduates of the Cuban film school. The goal is to empower the fellow filmmaker, because people are working in advertising throughout the year and I tell them to keep a little window available [...] to come to AcampaDOC in September. So, people come here because there are no other spaces here in Central America that allow us to be teachers. The universities do not allow us to enter to teach classes and a large part of that need is covered here. For three, four years, I had a lot of people who return, year after year, for that experience. Because every time you teach, you grow. When you give, you receive. (Ruiz Figueroa, I., personal communication, 14 September 2018; own translation).

The festival director mentions "the Cuban film school" as an institution that underlies the festival's pedagogical principles. She graduated the production specialization among the sixteenth generation of EICTV's regular course students, having attended from 2004 until 2007. The fact that EICTV is a strong marker of one's (cinematographic) identity and a label of trust and quality becomes evident through her answer about the motivation that preceded the establishment of the festival:

I arrived more than twelve years ago as a producer who graduated from the Cuban Film School. Previously, I had studied electronic engineering and I came with a motivation to do something that would bring us together as recently graduated filmmakers to talk about the nation's cinema. These were Panamanians and foreigners, young people [...] who did not find a poorly named 'industry' that many want to see in our countries. There was no educational strategy here in Panama. At the time, there was very little documentary production going on when I arrived, and there were no collectives or people who wanted documentaries or even understood what a documentary was about. (Ruiz Figueroa, I., personal communication, September 14, 2018; own translation).

EICTV functions as the common ground from whence many film professionals have initiated their careers in the Central American and Caribbean region, and it inspired its graduates to engage in the organization of film schools elsewhere. Between 1987 and 2015, at least 108 Central Americans have completed the three-year regular course at EICTV with a specialization in either direction, documentary, editing, photography, screenwriting, production, sound or television, and new media (Irigoyen Sánchez \& García Prieto, 2016). Many others ${ }^{3}$ have benefitted from shorter workshops and intensive 


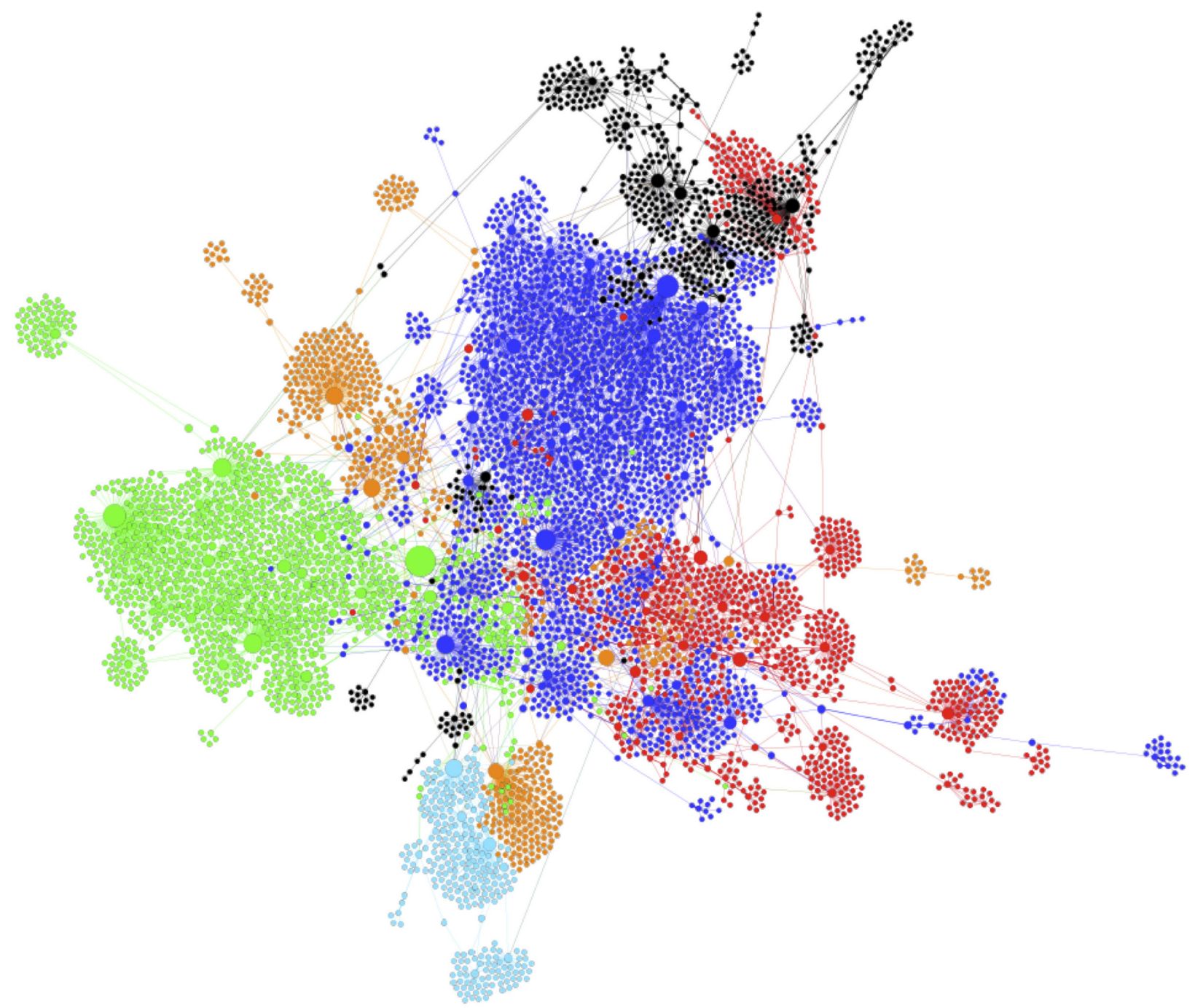

courses of up to six months offered by the school. The school has had one Central American general director, Guatemalan filmmaker Rafael Rosal, from 2011 until 2013.

The directors and tutors of AcampaDOC are similarly linked through their time spent at EICTV. Most notably, the school formed an essential institution for festival director Irina Ruiz Figueroa (2004-2007), production coordinator Hugo Koper (2005-2008), cinematography tutor Daniela Sagone (1999-2001), script tutor Edgar Soberón Torchía (EICTV script lecturer), programming assistant Milko Delgado (2015-2018), and sound tutor José Rommel Tuñón (2005-2008). According to the network analysis of productive relationships in Central American filmmaking, these collaborators occupy central positions in the network.

For example, Guatemalan producer and filmmaker Hugo Spencer Koper Pennington has both professional and family ties to the Ícaro Festivalorganizing institution Casa Comal in Guatemala. In network analysis-terms, he is a direct link, a socalled strong tie (Granovetter, 1973), because he can be considered a bridge between communities by connecting the Casa Comal, EICTV, and AGAcine communities of filmmaking from Guatemala and Cuba, each with their own links to other interlinked "clusters" of cinematographic production, 
to the creative alliance of film festivals in Panama and the Ibero-American student filmmakers who converge at the AcampaDOC Documentary Film Festival.

Secondly, Panamanian sound specialist José Rommel Tuñón is, in fact, Central America's most prolific contemporary film professional, for having been credited in at least twenty-eight feature films from all Central American countries, excluding work done outside of the region. After studying at EICTV, Tuñón worked on several of Casa Comal's films in addition to, among others, Julio Hernández Cordón's Buy me a Gun (2018) and Lightning falls behind (2017, IFFR premiere) and other festival award-winning films such as Ana Endara's La Felicidad del Sonido (2016, Panama). Tuñón is a regular presence at Central American film festivals such as IFF Panama, AcampaDOC, Ícaro and many others as a tutor, participant or guest. He has taken up teaching positions in several institutions, including at Casa Comal in Guatemala and AcampaDOC in Panama. In the network visualisation in Figure 1 , he is easily recognisable as the largest dot in the centre of the network, connecting to elements from all other clusters. His centrality in the network indicates that he is among the most well-connected film professionals to promote regional cinematographic integration through border-transgressing work.

\section{Empowering the fellow filmmaker}

New Latin American cinemas and its diversity of principles, the reunions of Third World-filmmakers, the Havana film festival and film schools like those in Santa Fe or San Antonio de Los Baños have contributed to the open-ended aestheticsideology that served as the foundation on which to build film cultures in the rest of the continent. The “anti-scholastic" school, according to EICTV's first director Fernando Birri, promotes the rejection of false oppositions between artisanal versus industrial, between polyvalence versus specialization, and between marginalization versus professionalism. In the school's opening statement, Birri foreshadowed one of Jacques Rancière's main arguments from The Ignorant Schoolmaster (1987) by equally rejecting the verticality of teaching:
Against the verticality of a teaching that descends from the top down, the Quetzalcoatl of the three levels is fulfilled, because our feathered serpent bites its own tail: the circular flow of teaching, the internal dynamics of the School, the overcoming of the false authoritarian antithesis and static teaching-learning. This is completely overcome by its opposite: "teach by learning" (Birri, 2016, p. 7).

The pedagogical Quetzalcoatl-principles as proposed by Birri and other Third Cinema-filmmakers are key to the formation of independent filmmakers in Central America. The EICTV promotes creative openness, vocation, and ideology. The school's ideology does not refer to socialism but to a humanist, and (re-)humanizing, perspective that got lost in colonial enterprises and Third-World-classifications, in order to be able "to express that which does not yet have a name, image or style, so the place of Utopia, that by definition is nowhere, will be somewhere" (Lord \& Zarza, 2014, p. 201). EICTV's principles, in which the utopia materializes through the creative acts of those who pass through it, extends through the region in collaborations that produce films, and festivals such as AcampaDOC.

\section{Central American cinema}

After talking to AcampaDOC's festival director about education, Cuba, and Latin American cinemas, the conversation turned to the implications for a Central American cinema as a distinct entity within Latin American cinemas as well as to the potential of film festivals in crafting a regionally oriented project. Can Central American cinema be seen as a distinct entity in the universe of Latin American cinemas? Her answer became a reflection of the ambivalence and cultural hybridity that characterizes the diversity of the Central American film landscape:

It is a question of yes and no. The first film camera arrived in Colón when Panama was still part of Colombia and as they saw that it was a jungle here, the camera was taken to Bogotá, the capital. From there on, we [Panama] were part of South America, but we have never considered ourselves South Americans, nor have we experienced the civil wars or social conflicts that the rest of Central America 
has, like our brothers to the North in Honduras or Guatemala. We are not Caribbean either because we are not on an island but we do have a lot of influence from Afro-descendants, from everything and everyone that came here for the construction of the Canal. I feel that we are geographically linked to Central America and we share the same eagerness. (Ruiz Figueroa, I., personal communication, 14 September 2018; own translation).

It seemed a precondition that, in order to be acknowledged as an established documentary tradition, it would have to be based on a resistance to colonial projects, strengthened through lived conflict and transferred traumas, based on racial tensions and social injustice, a common struggle of living among a polarized population under authoritarian regimes, of suffering exploitation by multinational corporations and large-scale agriculture or other industries. The Third Culture in which documentary cinema thrived is often based on this perpetual resistance and opposition to the capitalist hegemony in the North. And yet, Central America both is and is not part of this particular tradition, among other reasons due to high levels of demographic diversity. Despite its limited geography, Central America is characterized by complex processes of conviviality and conflict that are simultaneously social, economic, political, ethnic, linguistic, and cultural in essence. Rather than imposing a strict categorization, the idea behind culturally integrating Central American films is a result of necessary mutual empowerment, in terms of film practices in small and precarious film cultures, but also in terms of cultural and ideological motivations, to celebrate diversity as richness:

Look at South America and you see a long tradition of documentary schools, let alone in Mexico and the rest of North America. But yes, there is a link that unites us with Central America because of the desire to claim our national and local cinematography. It is not that we are going to differentiate the type of cinema but there is a special gaze that seeks that recognition, and it has not found it yet, it is still emerging. One cannot yet speak of a trend in Central American cinema as such. We have been doing it for more than twenty and a few years, since Ícaro is Ícaro in Guatemala, and I think that in just ten years we are going to consolidate something. (Ruiz Figueroa, I., personal communication, 14 September 2018; own translation).
The question of regional cultural appeal has been raised along with the cinematographic expansion over the past two decades. For AcampaDOC, the emphasis on documentary cinema and on the specific themes mentioned above, is inherent to sensitize people into more sustainable lifestyles and practices:

I think that the main role that a film festival can have, at least in the case of AcampaDOC, is to develop in order to safeguard our heritage by focusing on documentary cinema, non-fiction cinema, to emphasize aspects linked to the rescue of tangible and intangible, cultural and natural heritage of Panama, Central America, Ibero-America, of the world. In that sense, we are a window, perhaps the only exclusive window in Central America that showcases and encourages [documentary filmmaking], so that new audiences are created each time content is exhibited. (Ruiz Figueroa, I., personal communication, 14 September 2018; own translation).

The festival's engagement with sustainability and community is also reflected in its awards, which consist of living trees that are planted in a nearby ranch after the festival. Awarded films and filmmakers receive a type of endangered tree together with a certificate including the coordinates of its location, which is where their award will grow and contribute to the nation's biodiversity. In fact, by merely being organized, the festival interferes with the city council's urban development plans to redesign and modernize the old colonial town of La Villa de Los Santos. It takes place in the former National School of Folklore, an old and worn out building which is saved from repurposing or demolition because a minimum amount of annual activities render it untouchable as a cultural heritage.

The core idea behind the festival is to foster a type of documentary filmmaking that could be regarded as exemplary in the Central American context: a reflexive, participatory, and transnational cinema that adheres to international standards of production, rooted in the community with which it dialogues through the visual arts rather than merely registering it. The physical and metaphorical bodies of films and filmmakers linked to the festival are inscribed in the territory of la Villa de Los Santos, or actually planted as trees in the case of the award winners. The festival's double didacticproduction strategy makes it both representative of 
and constitutive of documentary filmmaking in the region, through the regular invitation of tutors and professionals linked to the region's film schools.

\section{The film festival network}

In 2017, the directors of AcampaDOC gave impulse to the creative alliance of the Panamanian Film Festival Network, a workgroup created to improve the sustainability, the outreach and impact of film festivals in all of Panama and in its diaspora. Concretely, the group implies an alliance between all of Panama's eleven film festivals and the Panama Film Festival in Los Angeles (PIFF LA), ensuring a positive diversity, exchange of materials, experts and films.

The Panamanian Film Festival Network was launched to promote, link and inform the diverse activities that member festivals offer throughout the year; to professionalize, articulate and promote the production of Panamanian film events; to share and benefit from the members' connections to grow $\mathrm{Pa}$ namanian film festivals; to establish a platform for updated resources, dates, calls and references for the general public, international distributors and other festivals that are interested in Panamanian film festivals. This support platform gathers data to inform media and audiences about activities; organizes workshops, articulates alliances and exchanges between member festivals; makes visible and strengthens festival management for institutions and distributors and supports those who are thinking about organizing showcases, screenings or new film festivals (Red panameña de Festivales de Cine, 2017).

\section{Conclusions}

Starting from the community and from the aspiring filmmaker, AcampaDOC's reach extends through the network it creates with every generation of students and tutors who join the festival and experience the intense conviviality of sharing time, space and ideas in the school of folklore. The seeds of documentary filmmaking and the preservation and celebration of heritage are sown, one by one, in the minds of the participants, students and tutors alike, who continue to cultivate and grow them after the festival in La Villa de los Santos ends. With direct and personal links to the region's foremost film schools and through the invitation of regional experts, AcampaDOC has transcended its function as an exhibition window for documentary films in the region.

In considering contemporary Central American film cultures as creatively small and precarious, the emphasis is on positive developments that have occurred in spite of the lack of public or state-support, and in spite of the unequal competition with larger film industries. As such, the 'precarious' does not refer to a lesser producer-status, to low-budget filmmaking or to peripheral developments in Latin American cinemas. Central American filmmaking can be seen as driven through various small-scale participatory and didactic initiatives that contribute to a transnational dynamic of exchange.

Film festivals in Central America occupy an important role in the development of regional film cultures as they have surfaced as important drivers of change regarding the creation of film laws, the connection to (co-)production platforms and as alternative circuits of exhibition. Such small film festivals do not necessarily include red carpets, stars or accreditation hierarchies, but instead invest in the training of emerging filmmakers and in the development of ongoing projects. In the absence of accessible film schools, some festivals offer unique hands-on opportunities to learn from and work with professionals from the field in a short and intense experience of producing films during the festival. Through the strategic invitation of tutors, experts and other professionals, festivals continuously expand and strengthen their network by connecting emerging talent with experienced talent, each with networks of their own.

\section{Notes}

1. While the last of the regional Peace Agreements were signed in 1996, the temporal starting point for the dataset is 1994, since El silencio de neto/The silence of Neto (Argueta, 1994) was the only fictional feature film released in the 1990s. 
2. Similar patterns can be seen in other parts of the documentary festival circuit (see Vallejo, 2017). The social essence of film festivals in strengthening film cultures is also elaborated in Peirano's contribution to Vallejo and Winton's Documentary Film Festivals (2020, pp. 55-72).

3. Concrete data for participants of the shorter courses is not readily available.

\section{Referencias}

Ahn, S. (2012). The Pusan International Film Festival, South Korean Cinema and Globalization. Hong Kong: Hong Kong University Press.

Alvarez, A., Arias, N., Hernández Cordón, J., Izquierdo, A. (Producers) \& Hernández-Cordón, J. (Director). (2017). Atrás hay relámpagos/Lightning falls behind [Film]. De Raíz Productions, Melindrosa Films.

Argueta, L. (Director). (1994). El silencio de Neto/The silence of Neto [Film]. Maya Media.

Balaisis, N. (2013). "The School for Every World: Internationalism and Residual Socialism at EICTV". In M. Hjort (Ed.), The Education of the Filmmaker in Africa, the Middle East, and the Americas (pp. 185-201). New York: Palgrave Macmillan.

Birri, F. (2016). "Fragmentos del acta de nacimiento". In S. Irigoyen Sánchez, \& M. García Prieto (Eds.), Memorias 30 años de la EICTV (p. 7). San Antonio de los Baños: Ediciones EICTV.

Burucúa, C. \& Sitnisky, C. (Eds.). (2018). The Precarious in the Cinemas of the Americas. New York: Palgrave Macmillan.

Castro, F. (2017). "Fragmento del discurso inaugural de la EICTV pronunciado por el Comandante en Jefe Fidel Castro Ruiz". In S. Irigoyen Sánchez, \& M. García Prieto (Eds.), Memorias 30 años de la EICTV. San Antonio de los Baños: Ediciones EICTV.

Durón, H. (2014). New Central American Cinema (2001-2010) [Unpublished doctoral dissertation]. University of Kansas.

Gálvez, I. (Producer) \& Endara, A. (Director). (2016). La Felicidad del Sonido [Film]. Mansa Productora.

Granovetter, M. S. (1973). The Strength of Weak Ties. American Journal of Sociology, 78(6), 1360-1380.

Falicov, T. (2019). Latin American Film Industries. London: British Film Institute. https:// doi.org/10.5040/9781911239376

Flew, T. (2018). Post-Globalisation. Javnost - The Public, 25(1-2), 102-109. https://doi.org/ 10.1080/13183222.2018.1418958 
Hernández-Cordón, J., Córdova, M. J., Ley, R., González, R. (Producers) and HernándezCordón, J. (Director). (2018). Cómprame un revolver/Buy me a gun [Film]. Melindrosa Films.

Hjort, M. \& Petrie, D. (Eds.). (2007). The Cinema of Small Nations. Edinburgh: Edinburgh University Press. https://doi.org/10.1017/S0165115310000148

Hjort, M. (2010). "Affinitive and MilieuQBuilding Transnationalism: The Advance Party Initiative". In D. Iordanova, D. Martin-Jones, \& B. Vidal (Eds.), Cinema at the Periphery (pp. 46-66). Detroit: Wayne State University Press.

Iordanova, D. (2015). The film festival as an industry node. Media Industries Journal, 1(3). https://doi.org/10.3998/mij.15031809.0001.302

Irigoyen Sánchez, S. \& García Prieto, M. (Eds.). (2016). Memorias 30 años de la EICTV. San Antonio de los Baños: Ediciones EICTV.

Lord, S. \& Zarza, Z. (2014). "Intimate spaces and migrant imaginaries: Sandra Gómez, Susana Barriga, and Heidi Hassan". In V. Navarro \& J. C. Rodríguez (Eds.), New Documentaries in Latin America (pp. 199-218). New York: Palgrave Macmillan.

Olivier de Sardan, J.P. (2015). Epistemology, Fieldwork, and Anthropology (T. Alou, Trans.). New York: Palgrave Macmillan.

Oyamburu, J. (Ed.). (2000). Visiones del sector cultural en Centroamérica. San José: Centro Cultural de España.

Peirano, M.P. (2020). "Connecting and Sharing Experiences: Chilean Documentary Film Professionals at the Film Festival Circuit". In A. Vallejo \& E. Winton (Eds.), Documentary Film Festivals Vol. 2: Changes, Challenges, Professional Perspectives (pp.55-72). Cham: Palgrave Macmillan.

Rancière, J. (1987). Le maître ignorant. Cinq leçons sur l'émancipation intellectuelle. Paris: Fayard.

Red panameña de Festivales de Cine. (2017). Red panameña de festivales de cine. https:// redpanafest.wordpress.com/

Sánchez, A. (2 July, 2018). No habrá festival de cine en el 2018, dice viceministro de Cultura. La Nación. https://www.nacion.com/viva/cine/no-habra-festival-de-cine-enel-2018-dice/XYIN6D0B55BW5MCKR0QG5FG50E/story/.

Shohat, E. (2004). "Post-third-worldist culture: gender, nation, and the cinema". In W. Dissanayake \& A. Guneratne (Eds.), Rethinking third cinema (pp. 63-90). New York: Routledge.

Tascón, S. M. (2015). Human rights film festivals: activism in context. New York: Palgrave Macmillan. https://doi.org/10.1057/9781137454249

Vallejo, A. (2017). "Travelling the Circuit: A Multi-sited Ethnography of Documentary Film Festivals in Europe". In A. Vallejo \& M.P. Peirano (Eds.), Film Festivals and Anthropology (pp. 277-292). Newcastle upon Tyne: Cambridge Scholars Publishing. 
- Sobre el autor:

Jasper Vanhaelemeesch obtuvo grados de maestría en literatura occidental y Cultures and Development Studies en la KU Leuven. Actualmente es estudiante de doctorado en el Visual and Digital Cultures Research Center (ViDi, Universidad de Amberes, Bélgica).

\section{- ¿Cómo citar?}

Vanhaelemeesch, J. (2020). The seeds multiply: the AcampaDOC International Documentary Film Festival. Comunicación y Medios, (42), 120-133. https://doi.org/10.5354/07191529.2020 .57277 